\title{
How Thierry Baudet Stole Geert Wilders' Votes: A Discourse Historical Analysis of Baudet's 2019 Provincial Elections Victory Speech.
}

\author{
Louis Talay \\ University of Sydney \\ louis.talay2001@outlook.com
}

\begin{abstract}
Thierry Baudet's remarkable success at the 2019 Dutch provincial elections was difficult to comprehend given the hitherto increasing popularity of the long-term dominant figure in Dutch far-right politics, Geert Wilders. Although both politicians preside over strikingly similar policy agendas, Wilders' supporters appeared to abandon him in favour of Baudet. This study attempted to investigate why Dutch far-right voters may have shifted their allegiance from Wilders's Partij Voor de Vrijheid to Baudet's Forum voor Democratie through a Discourse Historical Analysis of Baudet's provincial elections victory speech and a corpus of Wilders' discursive texts. Prior to commencing this analysis, the study's methodological approach for addressing such a complex topic was justified by means of demonstrating the close interrelationship between context, discourse and political strategy. The analysis discovered that Baudet distinguishes himself by constructing a less repressive guise for his party through careful characterisation of the Dutch identity rather than demonising the cultural enemy like Wilders and other leaders of the new right.
\end{abstract}

Key words: Populist discourse, Dutch identity, Dutch politics, European nationalism, Refugee discourse, Islamophobia

\section{Introduction}

The results of the most recent Dutch provincial elections, held on 20 March 2019, were remarkable for one reason in particular: A new right-wing populist party, Forum voor Democratie (FvD), won the most votes. Due to the nature of the Dutch indirect electoral system in which elected provincial councillors determine the composition of the national senate two months after the elections, the FvD were then able to obtain the equal most seats in the 75-seat senate (12). The centre-right Rutte government has now lost its majority in the upper house, which further restricts its already limited legislative capacity that up until these elections relied upon a four-party coalition to pass laws. Although these outcomes are unlikely to result in the FvD forming government at the next national elections in 2021, as the national electorate is highly fractionalised and major parties have repeatedly stated their aversion to forming a coalition with rightwing populist parties, the FvD will nevertheless have considerable influence over policy decisions throughout the remainder of this political term. Moreover, they will give the party and its young, charismatic leader, Thierry Baudet, an ideal platform for shaping future policy preferences in the Netherlands and, to a certain extent, at the European 
level, where the party will look to enlarging its current share of just under $11 \%$ of Dutch votes in the European Parliament.

Right-wing populism is not new to the Netherlands. Geert Wilders' Partij Voor de Vrijheid (PVV) has been relatively successful at both national elections and European parliament elections since the party's inception in 2006 and Wilders' profile is arguably bigger than that of any other Dutch politician of his era; both at home and abroad. Prior to Wilders, Pim Fortuyn - who was assassinated in the lead up to the 2002 Dutch national elections by a local animal rights campaigner in order to "defend Dutch Muslims from persecution" - had also given salience to policies of the extreme right (Evans-Pritchard and Clements, 2003). However, neither Wilder's PVV nor Fortuyn's Lijst Pim Fortuyn has enjoyed as much success at a national senate election as the FvD achieved earlier this year. Fortuyn's successors won 1 and o seats at the 2003 and 2007 elections respectively, while the PVV achieved its best result in 2011, winning $12.74 \%$ of the overall vote and 11 seats. Despite only forming at the end of 2016 and winning 1.78\% of votes and 2 seats at the 2017 national general elections, Baudet's popularity has surged in a short period of time, winning the greatest number votes at the senate elections of 2019 at $15.87 \%$. Interestingly, Wilders' public appeal appeared to be on the rise until the recent elections, having ranked fourth at the senate elections in both 2011 and 2015 before winning $13.1 \%$ of the overall vote to rank second at the most recent lower house elections in 2017. However, this trajectory was reversed at the 2019 provincial elections where the party pulled in only $6.46 \%$ of the nation's votes to rank seventh. So while it arguably comes as little surprise that there was considerable public support for right-wing populism at the recent Dutch provincial elections, the question is why was that support redirected from an established right-wing populist party that appeared to be expanding its influence to a new one that has very similar policies and virtually no presence in the house of representatives?

Two explanations of this outcome tend to be offered by commentators. The first is that Baudet is simply more eloquent and presentable than Wilders, which in turn convinces those with far right-wing preferences that he is more capable of securing their interests. The second argues that Baudet's policy agenda, while similar to Wilders', diverges in subtle ways to give it a less repressive guise without compromising key right-wing interests. In each case, the political discourse of both leaders is of fundamental importance; eloquence and presentation refer directly to one's public addresses while policy agendas are predominantly justified through discursive means.

Accordingly, the objective of this paper is to firstly demonstrate the significance of discourse in identity politics and to secondly develop a clearer understanding of the discursive means through which Baudet attempts to influence policy preferences and distinguish himself from Wilders. In order to achieve this, a comprehensive explanation of the study's methodological framework will be provided before conducting a Discourse Historical Analysis (DHA) of Baudet's March 21 victory speech. The reason this particular text has been selected for the analysis as opposed to other speeches that have been delivered by Baudet over the course of his short political career is because it captures his vision for Dutch civilisation in the midst of what many commentators label a "refugee crisis" or "identity crisis." Consequently, the analysis will focus exclusively on areas of the selected text that concern national identity, Dutch history, immigration and refugee settlement. Throughout the DHA, Baudet's text will be compared with a selected corpus of Wilder's political speeches. While it may appear a little arbitrary to select segments from different speeches of Wilders as opposed to focusing on one of his 
discursive texts in the analysis, none of his victory speeches have been as elaborate as Baudet's nor have they attempted to frame the refugee situation, despite the latter being an integral part of Wilders' political agenda. Therefore, it is believed that an analysis of a corpus of his addresses will enable a more accurate discursive comparison for the purposes of this study. The next sections will explain in further detail the political context of Baudet's address, discussing the dynamics of the European refugee situation and the recent history of immigration and refugee settlement in the Netherlands. Following this, the literature on populism and critical discourse analysis will be reviewed and then the DHA of Baudet's victory speech will be conducted. The paper will conclude with an evaluation of the discursive means through which Baudet attempts to distinguish himself from Wilders along with a recommendation for future research on this topic.

\section{European Refugee Situation}

Although Western Europe has a long history with migrants and refugees, the arrival of over 1 million people from the Middle East and elsewhere in 2015 represented a challenge that the European Union and its member states were unprepared for (European Parliament, 2017). The majority of these migrants were escaping conflict in Syria or other locations in the region and thus, would be regarded as "asylum seekers," under the definitions provided in the 1951 UN Refugee Convention (the convention) (Millbank, 2000). Nearly all of these asylum seekers were of Muslim faith and arrived in Europe after having made the dangerous journey across the Mediterranean on overcrowded boats departing from Northern Africa or Turkey. This became particularly problematic because most of these boats arrived in Greece: an EU member state that has been plagued by economic problems in recent times and hence lacking the resources to handle the crisis.

While policymakers may have felt that measures were already in place to manage this task, including the logistical support of the European Border and Coast Guard Agency and the open borders policy known as the Schengen Agreement, the policy response and debates that ensued among EU member states were anything but convergent. National responses varied across a range of policy agendas from those advocating open borders, such as Germany, to those opposing the arrivals by erecting fences along border hotspots and by waging powerful political campaigns, such as Hungary. The Schengen Agreement gives European citizens de jure access to the labour market, education system and welfare state of each signatory state. However, it does not oblige these states to accept any number of Muslim asylum seekers (MAS), who are, in effect, attempting to obtain the equivalent citizenship rights of a European citizen through refugee status. Furthermore, while International law theoretically compels signatories of the convention to accommodate asylum seekers and uphold minimum treatment standards, it is lexically ambiguous in places and lacks even the most basic enforcement instrument to ensure compliance and so refugee policy remains very much a national competency (Millbank, 2000).

This legislative context in combination with Europe's geographic composition (multiple countries within relatively close proximity to each other) has rendered the refugee situation even more problematic because MAS have been traversing the continent to find the most comfortable living environment, whether that be driven by reasons of family reunification, employment or welfare support. The failure of the EU and its member states to initiate any form of coordinated effort to accommodate the newly 
arrived MAS has resulted in many commentators (including the European Parliament) referring to the situation as the 'European refugee crisis.' This term has often been accompanied by inflammatory language that politicians and the media deploy to arouse fear of MAS among voters, which in turn, can generate support for anti-refugee sentiments.

\section{Immigration and Refugee Settlement in the Netherlands}

In the second half of the twentieth century, the Netherlands became more culturally diverse than it had ever previously been due to the arrival of large numbers of guest workers from Turkey, Morocco, Italy and Spain along with the post-colonial immigration of Indonesians and Surinamese people (Engbersen et al, 2003). However, most of these migrants were received in order to satisfy local interests such as the need to boost the labour supply in the nation's rapidly expanding industries of the 1950 s and 60s. The arrival of Indonesians after decolonisation in 1945 was complicated by the Dutch government's tier system that gave preference to those with European roots and arguably heralded the country's fear of cultural incompatibility that would become a major theme at all significant immigration debates to the present day. While the Netherlands took in thousands of refugees from Hungary, the Baltic states, Angola, Vietnam and Yugoslavia over the latter half of the twentieth century, the country was very much divided as to whether such a commitment should be made, given the alleged cultural problems associated with refugee settlement (Vogel, 2000).

Despite being widely regarded as a nation that espouses tolerance for minority groups, this polarisation with respect to attitudes towards refugees appears to have persisted in the present context to some extent. Recent large-scale value surveys have demonstrated that the majority of Dutch people believe their country should take in more refugees (Connor, 2018; Klaver, 2016), but these results tend to have little impact on policy outcomes, as reflected in the consistent success of far right-wing political parties in the country since the start of this decade. This apparent inconsistency is possibly due to the fact that far-right wing voters in the Netherlands are more interested in politics than the average Dutch person and that voting is not compulsory in the Netherlands, so those who are less passionate about political matters can simply avoid the polling booths (Van Steenbergen, 2016). Nevertheless, as Besselink (2008) points out, since the turn of the century several legislative developments have also made it more difficult for foreign cultures to integrate into Dutch society. Not only have sanctions for inadequate integration been tightened in the form of the Act on Civic Integration Abroad 2006 and the Civic Integration Act 2007, but also the conditions that constitute adequate integration have become a lot more difficult to attain; with the Aliens Act 2000 requiring prospective citizens to pass an oral language exam before they arrive in the Netherlands.

All this considered, the success of the PVV and FvD in recent times is somewhat surprising given Dutch society's progressive reputation and its considerable experience with foreign cultures and refugee settlement. In the latter case it should be noted that the intake of Yugoslavian refugees in 1994 registered very similar numbers to those recorded in 2015, which was the year in which the Netherlands received the most asylum applications in the context of the current refugee situation (VluchtelingenWerk Nederland, 2019). However, an important distinction between these two cases is that the current situation has occurred after a period of sustained tension between the Western World and Islam in which a series of brutal terrorist attacks have taken place (Glynn, 2017). This has enabled right-wing populist parties to arouse culture-based fears 
surrounding refugee policies that almost exclusively concern asylum seekers of Muslim faith.

\section{Populism}

In contemporary Europe the term 'populism' is often used to loosely categorise parties that challenge the political status quo or offer new and alternative policies to mainstream parties. However, several scholars have taken issue with generalisation and sought to provide a more precise definition to facilitate future comparative research. Interpretations have varied from a political strategy that centres itself on the persuasive powers of a charismatic leader (Weyland, 2001) to one that emphasises a strong connection with 'the people' (Taggart, 2000) to those that argue the term denotes an adherence to a "thin-centered ideology that considers society to be ultimately separated into two homogenous and antagonistic groups, 'the pure people' versus 'the corrupt elite' (Mudde, 2004, 543; Mudde \& Rovira Kaltwasser, 2012; Stanley, 2008). Van Leeuwen (2014) postulates that populism distinguishes itself from mainstream politics through the regular use of categorical statements and absolutes.

Despite this inconsistency, two recent publications have identified three features that regularly appear in the literature and touch aspects of most interpretations. Kaltwasser et al (2017) noted that studies in multiple continents since the late 19th century all distinguished populism from other political strategies for its direct appeal to 'the people' (often portraying them as "inherently virtuous and dutiful or disadvantaged), its fierce opposition to the establishment and its attempt at cultivating nationalistic sentiments. Comparably, Moffit (2016, p45), who focussed on more recent literature and political discourse, argued that populism is "a political style that features an appeal to "the people" versus "the elite", "bad manners" and the performance of crisis, breakdown or threat." Within their respective analyses of the aforementioned features, both of these publications emphasise the significance of the populist leader's 'presentation', which as mentioned in the introduction, is largely constructed through discursive means. This departure point is based on the substantial critical discourse analysis (CDA) literature that supports the theory that discourse is both "socially constituted and socially constitutive", meaning that it shapes social movements and cultural practices while also being shaped by them at the same time (Reisigl and Wodak, 2009: 89). This literature will be reviewed in the upcoming section of the paper.

\section{Discourse Historical Analysis}

The field known as CDA (also referred to as Critical Discourse Studies) is best described as a heterogeneous school of methodological approaches to discourse analysis that was established in the early 1990 s by a group of sociolinguists. Three of the scholars responsible for its establishment, namely Ruth Wodak, Teun Van Dijk and Norman Fairclough, have all constructed different CDA frameworks over the past few decades, but they all share a common theoretical nexus around the principle of interdisciplinarity along with a belief in the close relationship between discourse and identity construction. Van Dijk's (1998) socio-cognitive perspective is underpinned by the 'ideological square' concept that emphasises the tendency of social discursive practices to create ingroup/out-group binaries whereby members of the former will extol their own identities and demonise those belonging to the latter group. Fairclough's (2003) socio-cultural approach focuses on the semiotic effects of institutions and how signifiers from various institutions conceptualise their identities in different ways. And finally, Wodak's (2001) 
DHA stresses the importance of the relationship between identity discourse and the broader socio-cultural and historical context and is particularly interested in the way such discourses are reproduced over time. Despite the nuanced variations, each of these methodological approaches incorporates an assessment of various external influences and social structures into the analysis. Moreover, CDA proponents such as the aforementioned scholars invariably underline the link between discourse, power and ideology.

"Discursive practices may have major ideological effects - that is, they can help produce and reproduce unequal power relations between (for instance) social classes, women and men, and ethnic/cultural majorities and minorities through the ways in which they represent things and position people" (Fairclough and Wodak, 1997: 258).

This belief undoubtedly explains why CDA scholars seek to uncover the manipulative discursive strategies of far right-wing politicians.

Wodak's DHA is the methodological framework that will be applied to this investigation because it appears to be the most comprehensive. Its multi-level contextual analysis is of particular importance to the selected text. The scholar's recent DHA works include an article on David Cameron's Bloomberg speech on the European Union (2018), a comparative assessment of the legitimisation of immigration control in European countries (2017) and an analysis of the media's portrayal of the British identity in the aftermath of a divisive speech from Ed Milliband (2016). Each of these studies were able to demonstrate a connection between multiple contextual dimensions, discourse formation and identity politics. By using the DHA framework in this paper, it is believed that the same discoveries will be made. Typically, the DHA integrates four different levels of contextual analysis in a recursive fashion:

1. the immediate language;

2. the intertextual and interdiscursive relationships between utterances, texts, genres, and discourses;

3. the extralinguistic social variables and institutional frames of the specific "context of situation";

4. the broader socio-political and historical context which the discursive practices under examination are embedded in and related to. (Reisgl and Wodak, 2001, p41)

Close engagement with this multi-level contextual analysis will facilitate the process of identifying the main genres of the text. The messages contained within the identified genres, and their pathos, will then be further deconstructed through frequent referral to three other frameworks that are regularly applied in DHA and CDA literature.

The first of these was developed by Wodak and colleagues in 1999 and attempts to categorise the nature of the discursive identity strategy adopted by a given communicator (Wodak et al, 1999). This original study deduced from its findings that far right-wing leaders typically deploy one of four discursive macro-strategies when framing the national identity:

- constructive strategies (aiming at constructing national identities)

- preservative or justificatory strategies (aiming at conserving or reproducing historical identity narratives) 
- transformative strategies (aiming at changing existing national identity narratives)

- destructive strategies (aiming at dismantling existing national identity narratives)

The importance of this framework lies in its function in sharpening our understanding of the communicator's vision and construction of the in-group/out-group demarcation. Following Van Dijk's (1998: 236) 'ideological square’ concept

"Xenophobic groups or parties may engage in racist actions, but usually deny that such actions are racist, and hence outside of the moral order. Instead, they will claim that it is 'natural' to make a distinction or even to establish a hierarchy between Us and Them, to accord priority to US, or to give preferential access to symbolic or material resources because of blood, soil or innate characteristics."

In other words, national identity narratives serve the purpose of demarcating in-groups from out-groups and subtly legitimating negative attitudes toward out-groups.

Because the above-discussed identity construction categories are constructed through discourse, it is also necessary to conduct a systematic linguistic analysis of any CDA text that is subjected to the former framework. Reisigl and Wodak's 2001 study on the Rhetorics of Racism and Anti-Semitism created a scaffold to facilitate such an analysis, distinguishing five linguistic strategies that right-wing leaders deploy within their exclusionist frames. These are described in table 1.

\section{Table 1: Exclusionary linguistic strategies}

\begin{tabular}{|l|l|l|}
\hline Discursive strategy & Description & Examples \\
\hline $\begin{array}{l}\text { Referential/Nomination } \\
\text { strategies }\end{array}$ & $\begin{array}{l}\text { How persons are } \\
\text { named or referred to } \\
\text { linguistically }\end{array}$ & $\begin{array}{l}\text { Metonymy - "Yanks" may linguistically } \\
\text { represent "Americans" } \\
\text { Synecdoche - "Allah" may linguistically } \\
\text { represent "Islam" } \\
\text { Metaphor - "Parasites" may linguistically } \\
\text { represent "Asylum seekers" }\end{array}$ \\
\hline $\begin{array}{l}\text { Strategies of } \\
\text { predication }\end{array}$ & $\begin{array}{l}\text { The traits, values or } \\
\text { features that are } \\
\text { attributed to certain } \\
\text { groups }\end{array}$ & $\begin{array}{l}\text { A speaker might attribute business } \\
\text { acumen to Jewish people or they might } \\
\text { stereotype Americans as people of white } \\
\text { ethnicity. }\end{array}$ \\
\hline $\begin{array}{l}\text { Strategies of } \\
\text { argumentation }\end{array}$ & $\begin{array}{l}\text { The means by which } \\
\text { the above positive or } \\
\text { negative attributions } \\
\text { are justified. }\end{array}$ & $\begin{array}{l}\text { "We have a right to exclude Muslims from } \\
\text { ethnicity) is a true American hero." } \\
\text { multiple gender rights laws." }\end{array}$ \\
\hline
\end{tabular}




\begin{tabular}{|l|l|l|}
\hline $\begin{array}{l}\text { Strategies of } \\
\text { perspectivization }\end{array}$ & $\begin{array}{l}\text { From what } \\
\text { perspective are } \\
\text { these } \\
\text { nominalisations, } \\
\text { attributions and } \\
\text { arguments } \\
\text { expressed? I.e. How } \\
\text { involved is the } \\
\text { speaker? }\end{array}$ & $\begin{array}{l}\text { Close involvement e.g., "I was raised by a } \\
\text { single mother and can truly appreciate the } \\
\text { great sacrifices made by women in our } \\
\text { society." }\end{array}$ \\
$\begin{array}{l}\text { Detachment e.g., "We've never known } \\
\text { Swedish people to be this malicious and } \\
\text { we don't know the full details of the } \\
\text { crime." }\end{array}$ \\
\hline $\begin{array}{l}\text { Strategies of } \\
\text { intensification and } \\
\text { mitigation }\end{array}$ & $\begin{array}{l}\text { The intensification } \\
\text { or modification of } \\
\text { the illocutionary } \\
\text { force of } \\
\text { discriminatory } \\
\text { utterances. }\end{array}$ & $\begin{array}{l}\text { Amplifying particles e.g., "We condemn } \\
\text { the utterly disgraceful acts committed } \\
\text { yesterday." }\end{array}$ \\
$\begin{array}{l}\text { Anonymisation by impersonalising } \\
\text { constructions e.g., "It seems fairly clear } \\
\text { that these people have little respect for our } \\
\text { community." }\end{array}$ \\
\hline
\end{tabular}

Taken from Reisigl \& Wodak, 2001.

As can be inferred from the previously explained quote from Van Dijk (1998) and the description of argumentation strategies in Table 1, legitimation also plays a significant role in national identity discourse. Its purpose is to frame the exclusionist aspect contained within the discourse as ethically justifiable, consequently stripping it of its racist and/or social discriminatory undertone. This enables ethnic discrimination to enter common discourse and reproduce itself over time. Although Van Leeuwen's (1996) four-category legitimisation model has featured more regularly in DHA literature, I will use Reye's (2011) framework in this study because I consider it slightly more informative. Whereas Van Leeuwen distinguished between authorisation (legitimisation through authority or institutions), rationalisation (legitimisation through utility), moral evaluation (legitimisation through ethical foundations) and mythopoesis (legitimisation through evocative storytelling), Reyes effectively preserved Van Leeuwen's first three categories and replaced mythopoesis with two categories that broaden the spectrum of legitimation strategies without compromising the storytelling approach. Reyes distinguishes between the following five legitimisation strategies:

- Legitimisation through emotions

- Legitimisation through a hypothetical future

- Legitimisation through rationality

- Voices of expertise

- Altruism

While there is considerable overlap with Van Leeuwen's framework, Reyes' first two strategies in particular allow for a more nuanced analysis, as the former encourages investigation of the myriad ways in which communicators elicit emotional responses beyond storytelling while the latter accounts for fear-mongering future hypotheticals that have tended to dominate RWNP discourse. All of the above three frameworks will be applied to the DHA of Baudet's 2019 provincial elections victory speech in the following section. As the address and local reactions are in Dutch, Dutch to English translation was necessary. I am responsible for all of these translations. 


\section{DHA - Baudet's Victory Speech}

In the immediate aftermath of the 2019 Dutch provincial elections of March 20, Thierry Baudet delivered what one of the largest Dutch national newspapers, De Volkskrant, described as "the most extraordinary victory speech in Dutch political history" (Tempelman, 2019). While the reason behind this summation from De Volkskrant appears to be limited to the address's pomposity and its originality, this DHA will demonstrate that most of its power lies in its subtlety. Throughout the analysis comparisons will be made with the discursive strategies commonly deployed by Geert Wilders in order to work towards the objective of acquiring a better understanding as to why the FvD appears to have replaced the PVV as the main populist party in the Netherlands, despite the latter having grown steadily in popularity in the years leading up to the recent elections while also sharing a very similar policy agenda with the FvD.

Baudet opens his address with a referential strategy that heralds one of the major genres of the text: intellectualism. He uses Hegel's metaphor "the owl of Minerva spreading its wings at nightfall" to compare the FvD and its supporters to the Roman goddess of wisdom (Baudet, 2019). This is somewhat unconventional for a far right-wing populist politician, as most of his contemporaries market themselves as leaders who are in touch with the 'true people' of the country and consequently use language that does not have connotations of elitism or the proverbial 'ivory tower'. Wilders, for example, has been described as someone who "embraces the image of a people's streetfighter" (Marlisa \& Keyzer, 2019) and is much more likely to use profanities in his addresses than metaphors that the majority of interlocutors would have to research to be able to properly interpret. In light of this latter point, Baudet's owl metaphor does not have a clear attachment to an established Dutch identity narrative that would allow it to resonate with the broader public. However, this section will later demonstrate how the message contained within the metaphor comes to represent an integral part of Baudet's constructive discursive strategy.

Following this introduction, Baudet deploys an argumentation strategy that at first glance appears to be similar to those often found in Wilder's discourse, but at closer inspection offers a more sophisticated - and arguably more convincing - frame for legitimising one of the far-right's most divisive policies. "We stand here tonight. At the eleventh hour, literally. In the middle of the debris of what was once the greatest and most beautiful civilisation that the world has ever known."

Wilders regularly evokes a sense of local as well as European and global crisis with expression such as "What a dump. What a mess" (Wilders, 2017) and referring to modern civilisation as "Eurabia" and "Nederabia" in response to his perception of the large presence of Arabic people (Wilders, 2007). The argument presented by both leaders is that uncontrolled immigration, or more specifically, the influx of foreign cultures, is responsible for the destruction of Dutch society. However, while both emphatically express their displeasure with the outcome of socio-political developments in the Netherlands, which itself is a straightforward intensification strategy, the means through which they deliver their arguments (argumentation strategies) differ strikingly. Whereas Wilders simply attempts to demonise the enemy or the 'cause' of the social crisis through unambiguous tirades against Muslim people, Baudet never specifies who is responsible for the demise of Dutch civilisation and instead allows the audience to easily infer who it is by clearly identifying who the "heirs to the greatest civilisation" are. A key dimension of Van Dijk's 'Us and Them' dichotomy is captured by Benhabib's 
(1996) pithy summary, "One is a Bosnian Serb to the degree to which one is not a Bosnian Moslem or Croat." In his victory address, Baudet deploys a constructive discursive macro-strategy to demarcate the Dutch in-group, which in turn encourages interlocutors to consider which out-groups need to be excluded in order to "drive a renaissance" of the 'great civilisation'. It is the efficacy of this construction strategy in combination with his use of several context-specific intensification strategies that position the audience to view Muslim people as the out-group that represents the greatest threat to Dutch society.

After generating a sense of crisis and lamenting the destruction of the 'greatest civilisation', Baudet tells his audience what constituted its eminence. "A civilisation that... has produced the most beautiful architecture, the most beautiful music and the most beautiful paintings."

While these qualities appear to be detached from ethnicity, by deconstructing their image in a historical context one recognises the racial preferences he is attempting to trigger. Not only is he attempting to construct a national identity around high culture and intellect, but by evoking memories of the most famous Dutch artists from the country's history such as Rembrandt and Van Gogh, he is applying a predication strategy that encourages the public to think of its in-group as a club for those with traditional Dutch surnames, or more specifically, people of white ethnicity. This becomes more apparent in the next lines of his address where he states, "Our country is a part of that civilisation family. But just like the other countries from our boreal world, we are destroyed by the people that are supposed to protect us."

As Tempelman (2019) points out, the term 'boreal' used to appear in former far-right French politician Jean-Marie Le Pen's speeches, largely because it was viewed as a 'chic substitute' for the term Aryan. The Oxford English dictionary defines it as "of the north or northern regions," which also has connotations of Aryanism, while Kleinpaste (2019) argues it has "long been recognised as the deafening dog whistle to white supremacists." Ultimately, Baudet's national identity frame constitutes a constructive discursive macro-strategy as opposed to a preservative or transformative one given that there does not appear to be an established narrative of the Dutch identity. The Dutch collective understanding has been described by sociologists as "weak" and "inarticulate", which they argue are qualities that are generally interpreted as a positive reflection of the nation's tolerance and flexibility (Versteeg, 2012; Pels, 2005).

The fact that most people would have to search for the meaning of 'boreal,' reinforces Baudet's identity frame, as it combines exclusionist nationalism with his projection of reason and intellect. He is attempting to steer away from the conventional far-right image of primitive nationalism that caters to the uneducated or the working class, and instead create an image for himself and his followers as informed nationalists who seek a future that prioritises artistic and intellectual excellence. This frame is maintained throughout the address through various discursive means. Firstly, he uses a voices of expertise strategy in which he presents figures that demonstrate the thoroughness of his election campaign to legitimise the source of his party's ideas. Then he deploys another subtle predication strategy whereby he quotes an Aryan Dutch poet in describing his motivation to enter politics. "The sun would never have stood out to me, if it did not continue to go down." Not only does the poetic verse contribute to the sense of social crisis by suggesting that Baudet would never have stood in the election if Dutch culture had not continued to deteriorate, but it portrays him as a man who is well educated and 
culturally enlightened. Thirdly, Baudet condemns the alleged disappearance of the Dutch language from local universities, interpreting the development as evidence that "people don't believe in the Netherlands anymore." This narrows the in-group down to people with a high level of control over the Dutch language, which in turn, further ostracises those who weren't born in the Netherlands. Although Wilders seldom identifies the Dutch identity, his image would undoubtedly fall in the conventional farright category as he prefers to refer to people such as fishermen from the culturally homogeneous community of Urk as "the true heroes of the Netherlands" and those "made our country great and prosperous" (Wilders, 2018). The extent to which Baudet applies the national identity frame represents the most significant point of difference between his discourse and that of Wilders.

While Baudet is determined to build an image for himself and his party that centres on intellect and high culture, he is careful to distinguish these characteristics from elitism. This distinction is rather unusual given populism's tendency to associate intellectualism with undemocratic governance and the corresponding literature's inclination to group anti-intellectualism with anti-elitism (Hayward, 2003). Nevertheless, like Wilders, Baudet separates himself from the political elite, by regularly berating figures or institutions that are connected to the incumbent government. In order to cast this group in a negative light, he uses several referential strategies to identify its members. According to Baudet, the Dutch political 'elite' consists of "a clique of stuck-up networkers," "power-seeking operators" and "bureaucrats...who have not read a book in their lives." He then signals his allegiance to the disgruntled voters of the far right who have historically condemned such elitists by repeating the phrase, "We are being undermined." Here Baudet is using a perspectivisation strategy as he is attempting to position himself as a victim of the oppressive policies of an elite class. Yet, unlike many right-wing populist politicians, including Wilders, Baudet does not attempt to intensify this victimhood argument with an associated frame of anti-intellectualism. It can be argued that Wilders even deliberately positions himself as intellectually inferior to the political mainstream in some of his discourse to dichotomise Dutch society into average citizens and an elite class. This is exemplified in his tweet in February 2017 in response to an accusation that he had made a contradictory promise, "Hey left-wing elitist losers enjoy my slip of the tongue, but we are going to de-islamitise the Netherlands very soon and that is not a slip of the tongue" (Wilders, 2017a).

On the contrary, Baudet links the elite with "stupidity" and - as mentioned previously characterises himself and his followers as academic and artistically inclined.

Because Baudet goes in to far more detail in identifying the traits and characteristics of the national in-group than Wilders, he does not need to characterise out-groups with the same level of precision as the latter. As mentioned earlier, Baudet never uses the word 'Muslim' or 'Islam' in his address. Rather he invites his audience to imagine Muslims by framing the in-group so clearly as Aryans and evoking Islamophobic sentiments through carefully constructed intensification strategies. In the latter case, he commences by seamlessly connecting the alleged economic problems of immigration to their cultural consequences by chastising "Economic nobody" Prime Minister Rutte for "allowing hundreds of thousands of people from totally different cultures to enter the Netherlands." His subtle mention of the government's rejection of the FvD's proposal to help return unthreatened Syrians back to their country in the same sentence could be interpreted as a referential strategy whereby Syrian refugees (invariably Muslim) epitomise these 'totally different cultures.' He follows this tirade with an unambiguous 
assessment of the terrorist attack that took place in Utrecht two days prior to the election. "An absolute crisis is looming for the police, in which our safety on the street, which can hardly be further secured, will be placed under even more pressure."

Because the vast majority of his audience was aware that the attack was carried out by a Muslim, Baudet is creating a link between the previous cultural incompatibility argument, Syrian refugees and terrorism. This encourages his audience to view all Muslims as cultural aliens who often become terrorists. This predication strategy is extended in the following sentence when Baudet collectivises "rapists, armed robbers and life-threatening people" and connects them to the hidden cultural dangers that manifested in the "disgrace" that was the attack. While such fear-mongering rhetoric can be perceived as a Legitimization through a hypothetical future strategy that Wilders regularly employs, again, it is important to recognise that Baudet does not directly demonise the 'enemy' and in doing so, arguably shirks the controversial 'Islamophobic' image.

\section{Conclusion}

This paper has attempted to understand the reasons for Thierry Baudet's FvD win over Geert Wilders' PVV as the most popular far right-wing political party at the 2019 Dutch senate elections. It was believed that a comparative DHA of Baudet's victory speech with a selected corpus of Wilders' discursive texts would be one of the most effective means to acquire such knowledge given that discourse underpins social movements, as it is both "socially constituted and socially constitutive" (Reisigl \& Wodak, 2009: 89). This rationale was comprehensively discussed in order to justify the study's methodology for what was a complex research question given its context and general composition. The DHA methodology systematised the process of analysing the selected discursive texts, which ultimately made the relationship between content, context and political strategy a lot clearer. Although the study was not able to provide a definite answer to the question as to why Baudet appears to have taken over from Wilders as the most popular far- right politician in the Netherlands, it did make some important discoveries.

The DHA generated three interesting insights with regards to Thierry Baudet's discursive strategy. Firstly, he appears to have the same fondness for intensification strategies as Wilders, emphatically denouncing the vision and behaviour of the incumbent government and the perceived or implied cultural enemy at regular intervals. This is very much related to the second discovery, which is that Baudet, like Wilders, attempts to create a sense of social crisis and mobilise the public around the pursuit of a return to a glorified past. Within this frame Baudet uses a straightforward predication strategy that is often seen in Wilders' discourse in which out-groups are portrayed as the people responsible for the demise of Dutch society. However, it is the extent to which the in-group and out-group is identified where Baudet distinguishes himself from Wilders. The final and most significant discovery of the DHA was that Baudet never explicitly identifies who the out-group or 'cultural enemy' is, which deviates considerably from Wilders' strategy of consistently demonising Islam. Instead, Baudet allows the audience to easily infer that Muslim people are the most threatening outgroup in Dutch society by employing an identity constructive strategy and clearly defining the Dutch in-group. Through this strategy he creates another point of difference from Wilders by emphasising his party's affinity with intellect and artistic creation rather than sticking with the conventional far right-wing image of simplicity and a connection with common folk. This constructive macro-discursive strategy arguably 
creates a rational and less xenophobic guise for the FvD without compromising the key preferences of far right-wing voters, which could have been a critical determinant of its success and the concomitant decline of the PVV at the 2019 Dutch senate elections. To generate more conclusive findings on this topic, one might consider a DHA of some of Baudet's other addresses or alternatively conduct a quantitative analysis on voter preferences from the elections.

\section{Bibliography}

Baudet, T. (2019) in Trouw (2019) "Spreektekst Thierry Baudet, verkiezingsavond 20 Maart 2019," 21 March viewed from https://www.trouw.nl/nieuws/spreektekstthierry-baudet-verkiezingsavond-20-maart-2019 be2a1539/.

Benhabib, S. (1996), Democracy and Difference: Contesting the Boundaries of the Political, Princeton University Press, New Jersey.

Besselink, L. (2008) Integration and Immigration: the vicissitudes of Dutch 'Inburgering'www.libertysecurity.org/IMG/pdf_Integration_and_immigration_the_v icissitudes_of_Dutch_inburgering_rev_.pdf.

Connor, P. (2018). https://www.pewresearch.org/fact-tank/2018/o9/19/a-majorityof-europeans-favor-taking-in-refugees-but-most-disapprove-of-eus-handling-of-theissue/.

European Parliament (2017) "Asylum and migration in the EU: facts and figures," viewed from http://www.europarl.europa.eu/news/en/headlines/society/20170629STO78630/asylum-and-migration-in-the-eu-facts-and-figures.

Evans-Pritchard, A., Clements, J. (2003) "Fortuyn killed 'to protect Muslims," The Telegraph, 28 March, viewed from https://www.telegraph.co.uk/news/worldnews/europe/netherlands/1425944/Fortuyn-killed-to-protect-Muslims.html.

Fairclough, N. (2003) Analysing Discourse: Textual Analysis for Social Research. London: Routledge.

Fairclough, N., \& Wodak, R. (1997). Critical Discourse Analysis. In T. Van Dijk (Ed.), Discourse Studies: A Multidisciplinary Introduction (Vol. 2, pp. 258-284). London: Sage.

Glynn, I. (2017) "How the spectre of Yugoslavia looms over EU's handling of the refugee crisis," The Conversation, June 17, viewed from https://theconversation.com/how-the-spectre-of-yugoslavia-looms-over-eus-handling-of-the-refugee-crisis79393 .

Engbersen, G., Snel, E., Leerkes, A., Van San, M., \& Entzinger, H. (2003). Over landsgrenzen: Transnationale betrokkenheid en integratie. Rotterdam: RISBO.

Hayward, J. (2003) Elitism, Populism and European Politics, Oxford Scholarship Online.

Kaltwasser, C., Taggart, P., Espejo, P., \& Ostiguy, P. (2017) "Populism: An Overview of the Concept and the State of the Art," The Oxford Handbook of Populism. 
Kelinpaste, T. (2019) "The new face of the Dutch Far-Right," Foreign Policy, 28 March, viewed from https://foreignpolicy.com/2019/03/28/the-new-face-of-the-dutch-farright-fvd-thierry-baudet-netherlands-pvv-geert-wilders/

Klaver, J. (2016) "Local response to the refugee crisis in the Netherlands: Reception and Integration," National Integration Evaluation Mechanism.

Marlisa, L., Keyzer, T. (2019) "Baudet streeft Wilders voorbij op rechts - ze willen beiden een Nexit, maar zitten niet op één lijn wat betreft immigratie,” Business Insider, 20 March viewed from https://www.businessinsider.nl/thierry-baudet-geertwilders/

Millbank, A. (2000) The problem with the 1951 Refugee convention," Australian Parliament Social Policy Group. Research Paper 5.

Moffit, B. (2016). The Global Rise of Populism: Performance, Political Style and Representation. Stanford, CA: Stanford University Press.

Mudde, C. (2004) 'The Populist Zeitgeist,” Government and Opposition, Vol. 39(4), pp. $542-563$

Mudde, C., \& Rovira Kaltwasser, C. (eds.). 2012. Populism in Europe and the Americas. Cambride: Cambridge University Press.

Pels, D. (2005) Een zwak voor Nederland: Ideeen voor een nieuwe politiek, Amsterdam: Anthos

Reisigl M and Wodak R (2001) Discourse and Discrimination: Rhetorics of Racism and Antisemitism. Routledge: London and New York.

Reisigl, M., \& Wodak, R. (2009) The discourse-historical approach. In: Wodak R. and Meyer M. (eds) Methods of Critical Discourse Analysis. London: SAGE, pp. 87-121.

Reyes A (2011) "Strategies of legitimization in political discourse: From words to actions," Discourse and Society 22(6) 781-807.

Stanley, B. (2008). “The Thin Ideology of Populism,” Journal of Political Ideologies, Vol. 13(1), pp.95-110.

Taggart, P (2000). Populism. Buckingham: Open University Press.

Tempelman, O. (2019) “De opmerkelijkste overwinningspeech in de Nederlandse politeke geschiedenis ontleed," De Volkskrant, 21 March viewed from https://www.volkskrant.nl/kijkverder/v/2019/minervas-uil-en-de-wedergeboorte-van-nederlandde-opmerkelijke-speech-van-thierry-baudet-ontleed/?referer=https\%3A\%2F\%2Fwww.google.com\%2F.

Van Dijk, T. (1998) Ideology: A Multidisciplinary Approach. London: SAGE.

Van Leeuwen, M. (2014). Systematic stylistic analysis. In: Kaal B, Maks I and Elfrinkhof A (eds) From Text to Political Positions: Text Analysis across Disciplines. Amsterdam: John Benjamins, pp. 225-244. 
Van Leeuwen T (1996) The Grammar of Legitimation. London: School of Media/London School of Printing.

Van Steenbergen (2016) https://www.nrc.nl/nieuws/2016/12/20/wie-trekt-er-eengrens-alleen-wilders-5788597-a1537411.

Versteeg, P. (2012) “The Discovery of Dutch Identity: A Critical Exploration," Dutch Reformed Theological Journal, Volume 53.

Vogel, J. (2009) Cultuur en migratie in Nederland. Nabije Vreemden. Een eeuw wonen en samenwonen. Sdu Uitgevers: Den Haag.

VluchtelingenWerk Nederland (2019) "Vluchtelingen in getallen" https://www.vluchtelingenwerk.nl/feiten-cijfers/cijfers/bescherming-nederland.

Wilders, G. (2007) "Islamic Activism Debate," speech, retrieved from https://www.pvv.nl/12-in-de-kamer/spreekteksten/484-inbreng-wilders-tijdens-debat-islamitischactivisme.html.

Wilders, G. (2017) "Debat over het eindverslag van de informateur" retrieved from https://www.pvv.nl/36-fj-related/geert-wilders/9537-debat-over-het-eindverslag-vande-informateur-30-mei-2017.html.

Wilders, G. (2017a) (@geertwilderspvv) “Hé linkse elitaire losers geniet van mijn verspreking, maar we gaan Nederland wel heel snel deislamiseren en dat is geen verspreking!” 26 February. 10:23 AM. Tweet>.

Wilders, G. (2018) “Inbreng Geert Wilders APB 2018," speech, 19 September, retrieved from https://www.pvv.nl/36-fj-related/geert-wilders/9832-inbreng-geertwilders-apb-2018.html.

Wodak, R. (2001) The discourse-historical approach. In: Wodak R and Meyer E (eds) Methods of Critical Discourse Analysis. London: SAGE, pp.63-95.

Wodak, R, de Cillia, R., Reisigl, M. and Liebhart, K. (1999) The Discursive construction of National Identity, Edinburgh: Edinburgh University Press (revised and shortened translation of Wodak, R, de Cillia, R., Reisigl, M., Liebhart, K., Hofstatter, K. and Kargl, M. 1998). 